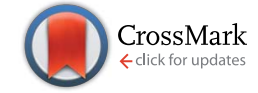

Cite this: J. Mater. Chem. A, 2015, 3, 19068

Received 15th August 2015

Accepted 17th August 2015

DOI: $10.1039 / c 5 t a 06421 j$

www.rsc.org/MaterialsA

\section{Highly efficient, coking-resistant SOFCs for energy conversion using biogas fuels $\$$ t}

\begin{abstract}
Jianjun Ma,§ Cairong Jiang,§ Paul A. Connor, Mark Cassidy and John T. S. Irvine*
Solid oxide fuel cells (SOFCs) afford an opportunity for the direct electrochemical conversion of biogas with high efficiency; however, direct utilisation of biogas in nickel-based SOFCs is a challenge as it is subject to carbon deposition. A biogas composition representative of a real operating system of $36 \% \mathrm{CH}_{4}, 36 \% \mathrm{CO}_{2}$, $20 \% \mathrm{H}_{2} \mathrm{O}, 4 \% \mathrm{H}_{2}$ and $4 \% \mathrm{CO}$ used here was derived from an anode recirculation method. A $\mathrm{BaZr}_{0.1} \mathrm{Ce}_{0.7} \mathrm{Y}_{0.1} \mathrm{Yb}_{0.1} \mathrm{O}_{3-\delta}(\mathrm{BCZYYb})$ infiltrated $\mathrm{Ni}-\mathrm{YSZ}$ anode was investigated for biogas conversion. The infiltration of $\mathrm{BCZYYb}$ significantly promoted the electrochemical reactions and the cells exhibited high power output at the operational temperatures of 850,800 and $750{ }^{\circ} \mathrm{C}$. At $800{ }^{\circ} \mathrm{C}$, supplied with a $20 \mathrm{ml}$ $\mathrm{min}^{-1}$ biogas, the cell with a BCZYYb-Ni-YSZ anode, generated $1.69 \mathrm{~A} \mathrm{~cm}^{-2}$ at $0.8 \mathrm{~V}$ with an optimal amount of 0.6 wt\% BCZYYb, whereas only $0.65 \mathrm{~A} \mathrm{~cm}^{-2}$ was produced with a non-infiltrated Ni-YSZ in the same conditions. At $750{ }^{\circ} \mathrm{C}$, a maximum power density of $1.43 \mathrm{~W} \mathrm{~cm}^{-2}$ was achieved on a cell with a BCZYYb-Ni-YSZ anode, a $3 \mu \mathrm{m}$ dense YSZ film electrolyte, a $\mathrm{Gd}_{0.1} \mathrm{Ce}_{0.9} \mathrm{O}_{2}$ (GDC) buffer layer and a $\mathrm{La}_{0.6} \mathrm{Sr}_{0.4} \mathrm{CO}_{0.2} \mathrm{Fe}_{0.8} \mathrm{O}_{3}-\mathrm{Gd}_{0.1} \mathrm{Ce}_{0.9} \mathrm{O}_{2}$ (LSCF-GDC) composite cathode. The cell remained stable, while operating at $0.8 \mathrm{~V}$ for 50 hours with a current density of $1.25 \mathrm{~A} \mathrm{~cm}^{-2}$. A well-designed cell structure and selected components made it possible to obtain excellent performance at good fuel utilisation. The analysis of gases in open-circuit conditions or under various current loads suggested that the prevalent reaction was reforming of methane without coking. This study demonstrates that the BCZYYb-Ni-YSZ is a promising electrode for carbon-containing fuel.
\end{abstract}

\section{Introduction}

Biogas, a renewable clean and easily controlled energy source, like solar and wind energy, is produced by the breakdown of organic matter in the absence of oxygen. It is an alternative to fossil fuels (petroleum, coal), not only to reduce an overall increase in greenhouse gases emissions, but to utilise a certain number of waste products, such as manure, sewage, municipal waste, plant material and crops residues. ${ }^{1}$ An underexploited potential energy source, biogas is composed of mainly methane (50-75\%) and carbon dioxide (25-50\%) with other minor gases. ${ }^{2}$ Because of the high level of carbon dioxide, it can only be utilised at low conversion efficiency levels in the conventional power generation system. Now it is being considered for use in alternative systems to generate electricity more efficiently. ${ }^{3-5}$

Solid oxide fuel cells (SOFCs) are a new technology for converting the chemical energy of hydrocarbon or biogas into

School of Chemistry, University of St Andrews, The Purdie Building, St Andrews, Fife, Scotland, UK, KY16 9ST. E-mail: jtsi@st-andrews.ac.uk; Fax: +44 (0) 133 4463808; Tel: +44 (0) 1334463817

$\dagger$ Electronic supplementary information (ESI) available. See DOI: 10.1039/c5ta06421j

\$ The research data supporting this publication can be accessed at http://dx.doi.org/10.17630/408942b8-b397-41ef-a932-ffc3bc6ced49

$\S$ These authors contributed equally to this work. electricity with high efficiency and fuel flexibility. ${ }^{6}$ SOFCs can operate within a wide temperature range from low temperatures $\left(400-600{ }^{\circ} \mathrm{C}\right.$ ) to high temperatures (over $1000{ }^{\circ} \mathrm{C}$ ) by selecting suitable electrolyte and electrode materials. Although operation of solid oxide fuel cells at low temperature is desirable in terms of cell life and cost, intermediate or even high temperature operation can be beneficial to the internal reforming reactions of methane or other hydrocarbon fuels. ${ }^{5,7-10}$ In addition, the direct heat exchange between the endothermic internal reforming reactions and the exothermic electrochemical reactions in the fuel cells increases the total system efficiency. ${ }^{\mathbf{1 1 , 1 2}}$

In general, steam reforming and dry reforming reactions are considered as the main reactions in a biogas-fuelled cell.

$$
\begin{aligned}
& \mathrm{CH}_{4}+\mathrm{H}_{2} \mathrm{O} \rightarrow \mathrm{CO}+3 \mathrm{H}_{2} \\
& \mathrm{CH}_{4}+\mathrm{CO}_{2} \rightarrow 2 \mathrm{CO}+2 \mathrm{H}_{2}
\end{aligned}
$$

There are, however, other reaction paths, such as the watergas shift reaction.

$$
\mathrm{CO}+\mathrm{H}_{2} \mathrm{O} \leftrightarrow \mathrm{CO}_{2}+\mathrm{H}_{2}
$$

Depending on the reaction conditions, the equilibrium for the water-gas shift can be pushed in either direction. In fuel cell systems, the dominant reactions will be dependent on the gas 
concentration, temperatures and system design. The task for researchers is to find good electrode materials that can operate in biogas fuel and generate good power output with good durability.

Nickel is a commonly used catalyst ${ }^{13}$ due to its excellent catalytic activity for direct oxidation or reforming reactions of hydrocarbon fuel. Therefore it is still considered to be a good catalyst for biogas conversion despite of extensive research on perovskite, $\mathrm{La}_{0.75} \mathrm{Sr}_{0.25} \mathrm{Cr}_{0.5} \mathrm{Mn}_{0.5} \mathrm{O}_{3}$ (ref. 14) and $\mathrm{Sr}_{2} \mathrm{Mg}_{1-x} \mathrm{Mn}_{x^{-}}$ $\mathrm{MoO}_{6-\delta},{ }^{15} \mathrm{Cu}$-based electrode (Cu-YSZ, Cu-Ceria), ${ }^{13,16}$ precious metal ( $\mathrm{Rh}, \mathrm{Ru}, \mathrm{Ir}, \mathrm{Pd}, \mathrm{Pt})^{17-20}$ or precious metal impregnated supports. ${ }^{16,21,22}$ However, when a nickel electrode is used in a biogas of $60 \% \mathrm{CH}_{4}$ and $40 \% \mathrm{CO}_{2}$, carbon coking occurs resulting in degradation of the cell performance, or even deactivation of the nickel electrode due to a build-up of carbon on the nickel surface. ${ }^{23-25}$ In order to avoid carbon deposition an additional reforming agent is therefore required. This could be air, steam or anode recycling containing $\mathrm{CO}_{2}$ and steam. It was reported that a high ratio of steam/methane (i.e., 2$)^{26}$ or carbon dioxide/methane (i.e., 1.5) ${ }^{\mathbf{1 0 , 2 7}}$ was needed for steam reforming and dry reforming, respectively. This dilutes the fuel concentration and subsequently reduces the fuel utilisation and electrical efficiency. Since SOFCs with anode gas recirculation have higher electrical and thermal efficiencies than non-recycling SOFCs, ${ }^{28,29}$ it is an effective strategy to combine dry reforming and steam reforming, because carbon dioxide and steam are available from partial anode exhaust gas recycling. ${ }^{30}$ In comparison with external steam generation, anode exhaust gas recycling provides an internal steam circuit, which eliminates the need for a waste heat recovery steam generator such as the boiler, thus reducing the capital cost of the system. At the same time, the steam content of the exhaust gas is reduced and this elevates efficiency of the total system, by increasing the sensible thermal energy of the exhaust gas.

Viana showed that good reverse water-gas shift activity was often associated with proton conducting oxide perovskites giving an early indication that these might be beneficial in anodes for hydrocarbon fuelled SOFC. ${ }^{31}$ Proton conductors, $\mathrm{BaZr}_{0.9} \mathrm{Yb}_{0.1} \mathrm{O}_{3-\delta}$, $\mathrm{BaZr}_{0.1} \mathrm{Ce}_{0.7} \mathrm{Y}_{0.2} \mathrm{O}_{3-\delta}{ }^{33}$ and $\mathrm{Ni}-\mathrm{BaZr}_{0.1} \mathrm{Ce}_{0.7} \mathrm{Y}_{0.1} \mathrm{Yb}_{0.1} \mathrm{O}_{3-\delta}{ }^{34}$ were also reported to have excellent resistance to sulphur poisoning. Cells with those proton conductors have been running in hydrocarbon fuels without coking and have been operating in high sulphur hydrogen without failure. A NiO-4\% $\mathrm{Zn}$, doped with $\mathrm{BaZr}_{0.8} \mathrm{Y}_{0.2} \mathrm{O}_{3}$ was used the anode for the $\mathrm{CH}_{4} / \mathrm{CO}_{2}=1: 1$ biogas with $3 \% \mathrm{H}_{2} \mathrm{O}$ and the cell displayed good durability even though carbon formation was thermodynamically favoured using this $\mathrm{CH}_{4} / \mathrm{CO}_{2}$ stoichiometric ratio, shown in the $\mathrm{C}-\mathrm{H}-\mathrm{O}$ equilibrium diagram. ${ }^{35}$ The application of $\mathrm{BaZr}_{0.1} \mathrm{Ce}_{0.7} \mathrm{Y}_{0.1} \mathrm{Yb}_{0.1} \mathrm{O}_{3-\delta}$ in biogas fuels has not yet been reported.

Apart from the carbon deposition, another important parameter to be evaluated in the use of biogas in SOFC, is the power output. Some researchers have performed some experiments to enhance the anode performance. The cell of Ni-BZYZn/BZYZn/Pt developed by Luisetto et al. ${ }^{35}$ generated a maximum power density of $20 \mathrm{~mW} \mathrm{~cm}^{-2}$ at $750{ }^{\circ} \mathrm{C}$, which was limited by a large ohmic resistance, and/or possibly by the poor catalytic activity of the electrode. Wang et al. reported a
Ni-based cell generated $424 \mathrm{~mW} \mathrm{~cm}^{-2}$ at $800{ }^{\circ} \mathrm{C}$ in a simulated biogas of $52.2 \% \mathrm{CH}_{4}, 46.3 \% \mathrm{CO}_{2}$ and $1.5 \% \mathrm{~N}_{2}$, but carbon deposition caused quick degradation of cell performance. ${ }^{36}$ This was improved by introduction of $\mathrm{Al}_{2} \mathrm{O}_{3}$, however, some carbon was still observed by SEM-EDX test after operation at $750{ }^{\circ} \mathrm{C}$ for over 120 hours.

At the operational temperatures of the solid oxide fuel cells, the cathode polarisation resistance is a major loss as well. ${ }^{37-39}$ This can be improved by choosing materials with high catalytic activity or by tailoring the microstructure. ${ }^{40,41}(\mathrm{La}, \mathrm{Sr})(\mathrm{Co}, \mathrm{Fe}) \mathrm{O}_{3}$ (LSCF), a mixed ion-electron conductor, was reported to have good electronic and ion conductivity and was suitable for intermediate temperature ranges $\left(700\right.$ to $\left.900{ }^{\circ} \mathrm{C}\right) .{ }^{42}$ Especially if low temperatures are desirable for the application.

In this study, we aim to develop biogas fuelled cells that they are coking free and have good durability combined with good fuel utilisation. Here a simple route will be developed to prepare a modified Ni-YSZ anode with $\mathrm{BaZr}_{0.1} \mathrm{Ce}_{0.7} \mathrm{Y}_{0.1} \mathrm{Yb}_{0.1} \mathrm{O}_{3-\delta}$ (BCZYYb) infiltration. Gas components will be detected in open circuit conditions and under current load to explore possible reaction mechanism.

\section{Experimental and theoretical calculation}

\subsection{Biogas composition}

Thermochemical calculations were carried out using the program, HSC chemistry (version 5.0, Outokumpu Research Oy, Finland). The details of these calculations can be found in the previous literature. ${ }^{43}$ The calculations were performed by assuming a reactor was supplied with a mixture of fuel gas normalized to $1 \mathrm{kmol}$, and the amount of gas, liquid, or solid products in thermodynamic equilibrium were numerically derived. This was performed over a temperature range of 100 to $900^{\circ} \mathrm{C}$ in steps of $10^{\circ} \mathrm{C}$. As solid carbon, only graphite was taken into account, although various carbon-based materials such as amorphous carbon, carbon nanotubes, and carbon nanofibers have slightly different thermochemical properties. As the equilibrium products can be in a gas state and/or a solid state (graphite) at elevated temperatures, most of the following results calculated in this study were shown as the amounts of products rather than concentrations. For the sake of simplicity, only the following species were considered: $\mathrm{H}_{2}(\mathrm{~g}), \mathrm{H}_{2} \mathrm{O}(\mathrm{g}), \mathrm{O}_{2}$ $(\mathrm{g}), \mathrm{CO}(\mathrm{g}), \mathrm{CO}_{2}(\mathrm{~g}), \mathrm{CH}_{4}(\mathrm{~g})$, and solid graphite. Chemical compositions were numerically derived by assuming complete thermodynamic equilibrium. The total pressure was 1 bar. Partial pressures were derived from the chemical compositions by assuming that fuel gases can be regarded as ideal gases.

A biogas of $63 \% \mathrm{CH}_{4}$ and $37 \% \mathrm{CO}_{2}$, which has a typical amount of methane for different feedstocks, was selected as an original biogas. ${ }^{2}$ This biogas is prone to form carbon at the operational temperatures (e.g. $750-850{ }^{\circ} \mathrm{C}$ ) of fuel cells (no. 1 biogas, in Fig. 1). We anticipate that a practical small system will utilise anode recirculation to minimise carbon formation and best utilise thermal energy and this would mean a modified biogas composition needs to be considered in solid oxide fuel 
cells. Starting from the original biogas composition (no. 1) methane will be converted into $\mathrm{CO}, \mathrm{H}_{2}$ according to reforming reactions and then oxidised. A typical overall fuel conversion rate of $80 \%$ was chosen and $25 \%$ of the anode exhaust could be recycled. An iterative method was used to calculate a steady-state composition. It was assumed that the gases were at thermodynamic equilibrium and the gas composition was calculated with HSC chemistry software. A single-pass fuel utilisation was $73.3 \%$. $25 \%$ of the anode exhaust gas was added into the original gas. Then the cycle described above was repeated until a steady-state composition of gases was obtained. The overall fuel utilisation was $80 \%$. This slightly higher overall fuel utilisation than a singlypass fuel utilisation of $73.3 \%$ matched the report by Powell et al. ${ }^{\mathbf{4 4}}$ Fuel utilisation will be discussed in Section 3.3. The final steadystate biogas is defined as a recirculated biogas and its composition was $36 \% \mathrm{CH}_{4}, 36 \% \mathrm{CO}_{2}, 20 \% \mathrm{H}_{2} \mathrm{O}, 4 \% \mathrm{H}_{2}$ and $4 \% \mathrm{CO}$. The details of the calculation were shown elsewhere. ${ }^{45}$ This recirculated biogas (no. 2, Fig. 1) is in the safe region and should not result in carbon deposition above $720{ }^{\circ} \mathrm{C}$. In the following, we will be using the recirculated biogas of $36 \% \mathrm{CH}_{4}, 36 \% \mathrm{CO}_{2}, 20 \% \mathrm{H}_{2} \mathrm{O}$, $4 \% \mathrm{H}_{2}$ and $4 \% \mathrm{CO}$ to do further research.

\subsection{Experimental}

2.2.1. Cell preparation. The anode supported cells used were made in the lab, as described elsewhere. ${ }^{46}$ The anode was a mixture of NiO (99.97\% Kojundo, Japan) and YSZ powder (TZ-8Y, Tosoh) in a weight ratio of 60 to 40 and the electrolyte of YSZ was 3-7 $\mu \mathrm{m}$ thick. The anode half-cell was then sintered at $1350{ }^{\circ} \mathrm{C}$ for 5 hours to get a dense YSZ electrolyte. A $\left(\mathrm{La}_{0.8} \mathrm{Sr}_{0.2}\right)_{0.95} \mathrm{MnO}_{3}$ (LSM) (PRAXAIR, surface area: $6.79 \mathrm{~m}^{2} \mathrm{~g}^{-1}$ )-YSZ or a $\mathrm{La}_{0.6} \mathrm{Sr}_{0.4} \mathrm{Co}_{0.2} \mathrm{Fe}_{0.8} \mathrm{O}_{3}$ (LSCF) (PRAXAIR, surface area: $9.24 \mathrm{~m}^{2} \mathrm{~g}^{-1}$ )- $\mathrm{Gd}_{0.1} \mathrm{Ce}_{0.9} \mathrm{O}_{2}$ (Rhodia, Anan Kasei Co. Ltd, Japan) was used as the cathode. The LSM-YSZ was screen-printed onto the surface of the YSZ electrolyte membrane and sintered at $1100{ }^{\circ} \mathrm{C}$ for 2 hours. For the LSCF-GDC cathode, $\mathrm{a} \mathrm{Gd}_{0.1} \mathrm{Ce}_{0.9} \mathrm{O}_{2}$ ink was screen-printed onto the YSZ electrolyte surface, and sintered at $1150{ }^{\circ} \mathrm{C}$ for 2 hours to get a cathode buffer layer, in order to prevent any inter-reaction between the LSCF cathode

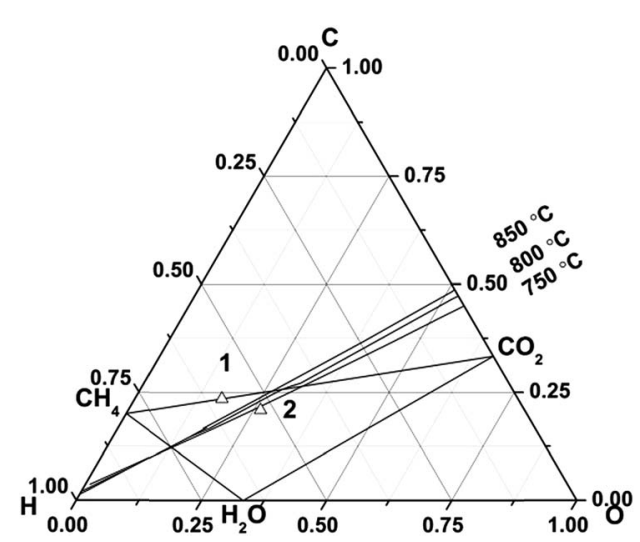

Fig. 1 An equilibrium diagram of the region for carbon deposition at $750-850{ }^{\circ} \mathrm{C}$ for an original biogas of $63 \% \mathrm{CH}_{4}$ and $37 \% \mathrm{CO}_{2}$ (no. 1) and a recirculated biogas of $36 \% \mathrm{CH}_{4}, 36 \% \mathrm{CO}_{2}, 20 \% \mathrm{H}_{2} \mathrm{O}, 4 \% \mathrm{H}_{2}, 4 \% \mathrm{CO}$ (no. 2). and the YSZ electrolyte. The LSCF-GDC cathode was sintered at $1000{ }^{\circ} \mathrm{C}$ for 2 hours. The weight ratio between the LSM and the YSZ, the LSCF and the YSZ, was $50: 50$ and $70: 30$, respectively. The thickness of the LSM-YSZ and the LSCF-GDC layers were around $20 \mu \mathrm{m}$. The cathode area, calculated as the cell active area, was $1 \mathrm{~cm}^{2}$. Platinum paste (Gwent Group, 70\%) and gold paste (conductor paste M-9875, METALOR Technologies UK Ltd) were used as the cathode and anode current collectors, respectively, sintering at $900{ }^{\circ} \mathrm{C}$ for 30 minutes.

2.2.2. Infiltration of BCZYYb. The anode half cells were infiltrated with a nitrate solution of the metal ions. First ytterbium(III) oxide $\left(\mathrm{Yb}_{2} \mathrm{O}_{3}\right.$, Alfa Aesar) was dissolved in diluted nitric acid (Fisher Chemical) and then zirconium(Iv) 2,4-pentanedionate (Alfa Aesar) solution was added. The mixture was heated until a clear solution was obtained. Barium nitrate $(99.9 \%$, Sigma-Aldrich) and cerium(III) nitrate hexahydrate (99\% trace metals basis, Sigma-Aldrich) and yttrium(III) nitrate hexahydrate (99.8\% trace metals basis, Sigma-Aldrich) were added afterwards. The solution, with the correct molar ratios, was mixed with citric acid (99.5\%, Sigma-Aldrich) and ethylenediaminetetraacetic acid (EDTA, purified grade, $\geq 98.5 \%$, Sigma-Aldrich) to produce a solution with a ratio of citric acid : EDTA : metal-ion $1.5: 1: 1$. A final solution was obtained by adjusting the $\mathrm{pH}$ value to $\sim 7$ with $\mathrm{NH}_{3} \cdot 6 \mathrm{H}_{2} \mathrm{O}$ (Fisher chemical), and this was then infiltrated into the NiO-YSZ anode substrate and calcined at $1100{ }^{\circ} \mathrm{C}$ for 2 hours. The infiltration amount used was $0.3 \mathrm{wt} \%, 0.6 \mathrm{wt} \%, 1.0 \mathrm{wt} \%$ and $1.6 \mathrm{wt} \%$ of the cell weight, accordingly the number of infiltration times were 2 , 3, 6 and 9. The cells with $\mathrm{BaZr}_{0.1} \mathrm{Ce}_{0.7} \mathrm{Y}_{0.1} \mathrm{Yb}_{0.1} \mathrm{O}_{3-\delta}$ (BCZYYb) were defined as BCZYYb-0 wt\%, BCZYYb-0.6 wt\%, BCZYYb-1.0 $\mathrm{wt} \%$ and BCZYYb-1.6 wt\%. The consequence of the cell preparation procedure was the half cell of the NiO-YSZ/YSZ was made first. And then when the LSM was used for the cathode, the LSM-YSZ and the infiltrated BCZYYb were sintered at $1100{ }^{\circ} \mathrm{C}$ for 2 hours. When the LSCF was used the cathode, the GDC interlayer was sintered $1150^{\circ} \mathrm{C}$, and then the infiltrated BCZYYb was sintered at $1100{ }^{\circ} \mathrm{C}$ for 2 hours and at last the LSCF-GDC electrode was sintered at $1000{ }^{\circ} \mathrm{C}$ for 2 hours.

2.2.3. Electrochemical test. The electrochemical tests were carried out on a cell with three-electrode configuration. The cell structure and a test jig are shown in Fig. S1. $\dagger$ The cell was mounted on an alumina tube with Aremco 552 sealant. Inside the alumina tube, a K-type thermocouple was used to record the temperature profile along the cell. The cells were heated in a house-built vertical tube furnace to $100{ }^{\circ} \mathrm{C}$ and $250{ }^{\circ} \mathrm{C}$ in a $5{ }^{\circ} \mathrm{C}$ $\min ^{-1}$ ramp rate and kept at these temperatures for an hour to cure the ceramic sealant; they were then heated to $850{ }^{\circ} \mathrm{C}$. The cells were protected in an argon atmosphere during the heating procedure. When it reached the target temperature, the cells were reduced by hydrogen, which was from a cylinder, and the cathode was supplied with flowing air. OCVs were checked to reach a constant value before electrochemical testing, to ensure an equilibrium state was achieved. Initially, the cells were characterised by measuring electrochemical polarisation curves and electrochemical impedance spectroscopy (EIS) in dry hydrogen by a Solartron 1280B frequency analyser. The EIS ranged from $20000 \mathrm{~Hz}$ to $0.1 \mathrm{~Hz}$ in open-circuit conditions. 
After the nickel oxide had been completely reduced to nickel, the anode gas was connected to a bubbler to humidify the hydrogen. It was then switched to a steam generator to gradually increase the steam content, until $20 \% \mathrm{H}_{2} \mathrm{O}$ was obtained. The water content during testing was monitored by a dewpoint sensor (Vaisala). A biogas with desired compositions was switched on. The gases were mixed to the correct ratio using mass flow controllers (Bronkhorst), with a total flow rate of a $300 \mathrm{ml} \mathrm{min}{ }^{-1}$, consisting of $285 \mathrm{ml} \mathrm{min}^{-1}$ of the biogas composition, balanced with argon. The cells were characterised in dry hydrogen, wet hydrogen, steam hydrogen and the recirculated biogas mentioned above. In the biogas, the cell was kept in open-circuit conditions for 2 hours to record the anode exhaust gas. The electrochemical polarisation curves and the EIS of the cells were tested from $850{ }^{\circ} \mathrm{C}$ to $750{ }^{\circ} \mathrm{C}$, at a $50{ }^{\circ} \mathrm{C}$ interval, using various flow rates. To simplify the experiments, the optimisation of infiltration BCZYYb was carried out on the cell with a LSM-YSZ cathode rather than a LSCF-GDC cathode, to avoid the extra work of the screen-printing of the GDC interlayer.

2.2.4. Gas chromatography. The anode exhaust gas was measured by an on-line gas chromatography, a HP 6890 series GC system. Before the gas was passed into the GC, a water trap was set up using dry ice. The GC inlet temperature was $60{ }^{\circ} \mathrm{C}$ and oven temperature was $40{ }^{\circ} \mathrm{C}$, to detect $\mathrm{H}_{2}, \mathrm{CO}$ and $\mathrm{CH}_{4}$ and then heated to $100{ }^{\circ} \mathrm{C}$ to detect $\mathrm{CO}_{2}$. The front detector temperature was $210{ }^{\circ} \mathrm{C}$. The column was HP-CarboPLOT with dimensions of $25.0 \mathrm{~m} \times 250 \mu \mathrm{m} \times 0.21 \mu \mathrm{m}$. 5\% Argon was added to the original gas mixture as the reference gas. The concentration of hydrogen gas detected from the GC might not have been accurate in this case. Therefore the practical hydrogen content was also calculated.

There should be no change in the carbon content in the original gas and in the anode exhaust gas as long as there is no carbon deposition.

Carbon content $\left(\mathrm{CH}_{4}+\mathrm{CO}+\mathrm{CO}_{2}\right)_{\text {input }}=$

Carbon content $\left(\mathrm{CH}_{4}+\mathrm{CO}+\mathrm{CO}_{2}\right)_{\text {output }}$

The flow rate of argon in input is equal to the flow rate of argon from output.

$$
f\left(\operatorname{Ar}_{(\text {input })}\right)=f\left(\operatorname{Ar}_{(\text {output })}\right)
$$

The content of $\mathrm{CH}_{4}$, $\mathrm{CO}$ and $\mathrm{CO}_{2}$ was recalculated by subtracting hydrogen and argon from the GC results.

The flow rate of hydrogen from output was calculated using the following equation:

$$
f\left(\mathrm{H}_{2} \text { out }\right)=2 \times\left(f\left(\mathrm{CH}_{4} \text { in }\right)-f\left(\mathrm{CH}_{4} \text { out }\right)\right)-f\left(\mathrm{H}_{2} \text { in }\right)
$$

Conversion rate of $\mathrm{CH}_{4}$ was calculated in $\left(f\left(\mathrm{CH}_{4}\right.\right.$ in $)-$

$$
\left.f\left(\mathrm{CH}_{4} \text { out }\right)\right) / f\left(\mathrm{CH}_{4} \text { in }\right) \times 100 \% \text {. }
$$

2.2.5. SEM analysis. The microstructure of the tested cells was observed by using SEM (Jeol FE-SEM 6700).

\section{Results and discussion}

\subsection{Cell structure}

A SOFC with a thin electrolyte film is desirable to achieve sufficient energy conversion rates and obtain a reasonable power output. ${ }^{47}$ Here a NiO-YSZ anode-supported fuel cell was developed with a thin YSZ electrolyte fabricated by slurry coating. ${ }^{\mathbf{4 6}}$ The microstructure of an example anode supported fuel cell (Ni-YSZ (BCZYYb-0.6 wt\%)/YSZ/GDC/LSCF-GDC) is shown in Fig. 2a. The thickness of the YSZ electrolyte membrane is about $3 \mu \mathrm{m}$ with neither crack nor pinhole, giving a very low ohmic resistance from the electrolyte due to the thin electrolyte. ${ }^{48}$ The interlayer of GDC is about $3 \mu \mathrm{m}$. Therefore, the cell performance of the anode-supported cell is dominated by the electrode polarisation $\operatorname{losses}^{49}$ from both the anode and the cathode. Fig. 2a shows that the Ni-YSZ anode has appropriate porosity for gas to pass through to the three-phase boundary, thus allowing participation in the reactions. The microstructures of Ni-YSZ anodes infiltrated with and without BCZYYb are shown in Fig. 2b. The framework of the anodes is covered with BCZYYb particles to form a layer. Clear boundaries of BCZYYb layers are observed around the edges of the pores. These layers of BCZYYb protect the Ni-YSZ from direct contact with the biogas.

\subsection{Electrochemical performance}

Fig. 3a compares the current densities obtained from differing cells with a infiltrated BCZYYb or a non-infiltrated BCZYYb-NiYSZ anode at $0.8 \mathrm{~V}$, as obtained from the current density-voltage curves (Fig. S2 $\dagger$ ). The optimisation experiments were performed on the cell configuration of BCZYYb-Ni-YSZ/YSZ/LSM-YSZ. All the infiltrated BCZYYb Ni-YSZ cells have a better cell performance than the non-infiltrated one. The infiltration of BCZYYb effectively enhanced the cell performance in all kinds of fuels, dry hydrogen, wet hydrogen, steam hydrogen or biogas. Of all the cells, Ni-YSZ/BCZYYb-0.6 wt\% generated the best cell performance.

Fig. $3 \mathrm{~b}$ shows examples of the performance of the cells tested in the recirculated biogas at $800{ }^{\circ} \mathrm{C}$ with infiltrated $\mathrm{BCZYYb}$. For the non-infiltrated Ni-YSZ cell, the current density was $0.65 \mathrm{~A}$ $\mathrm{cm}^{-2}$ at $0.8 \mathrm{~V}$. After the infiltration, the cell performance increased dramatically and the current density reached $1.69 \mathrm{~A}$ $\mathrm{cm}^{-2}$ when $0.6 \mathrm{wt} \%$ BCZYYb was infiltrated into the electrode. Any further increase in the infiltration amount resulted in a drop in the cell performance, but these were still better than the performance of non-infiltrated Ni-YSZ.

The impedance spectra of the cells are shown in Fig. 3c. The polarisation resistance $R_{\mathrm{p}}$ of the cell with the non-infiltrated Ni-YSZ anode was $0.275 \Omega \mathrm{cm}^{2}$. After infiltration with $0.3 \mathrm{wt} \%$ BCZYYb, the $R_{\mathrm{p}}$ decreased to $0.206 \Omega \mathrm{cm}^{2}$. Further increasing the infiltration amount to $0.6 \mathrm{wt} \%$, the lowest $R_{\mathrm{p}}$ of $0.131 \Omega \mathrm{cm}^{2}$ was obtained. It seemed that this was an optimal amount as additional increase in the infiltration amount would not further improve the polarisation resistance. The $R_{\mathrm{p}}$ of the cell infiltrated with $1.0 \mathrm{wt} \%$ and $1.6 \mathrm{wt} \%$ BCZYYb was 0.225 and $0.265 \Omega \mathrm{cm}^{2}$. From the simulation of the impedance resistance, electrochemical reactions at both high-frequency (assigned to charge 
a

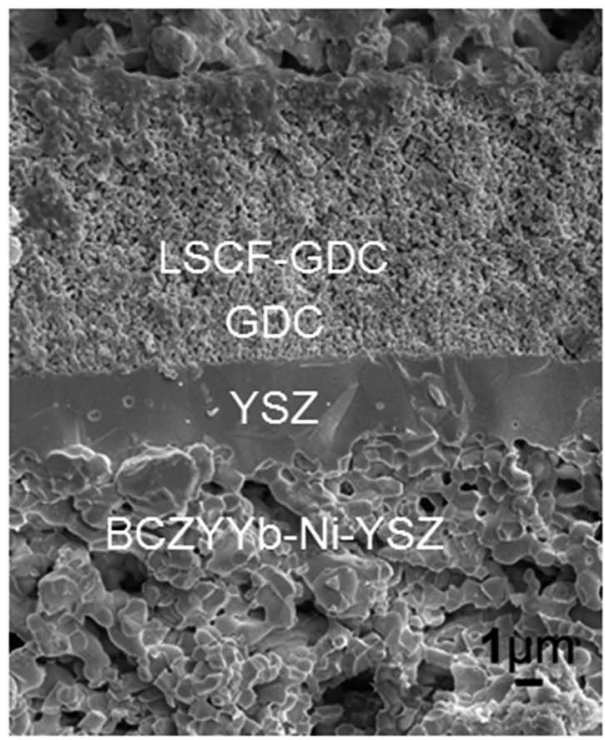

b
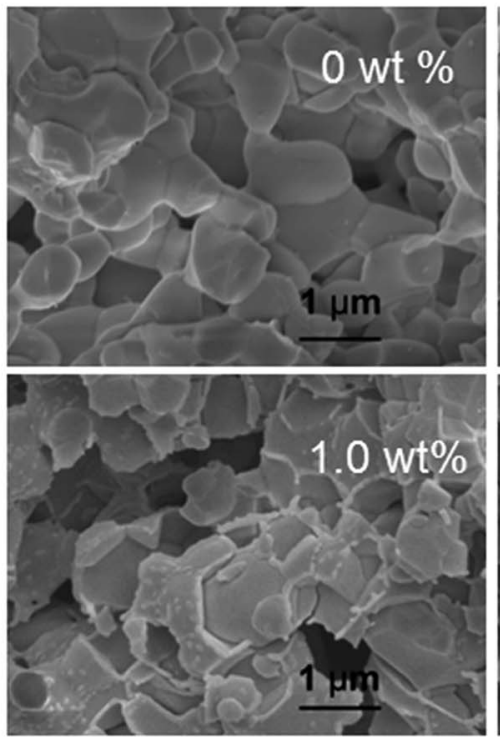
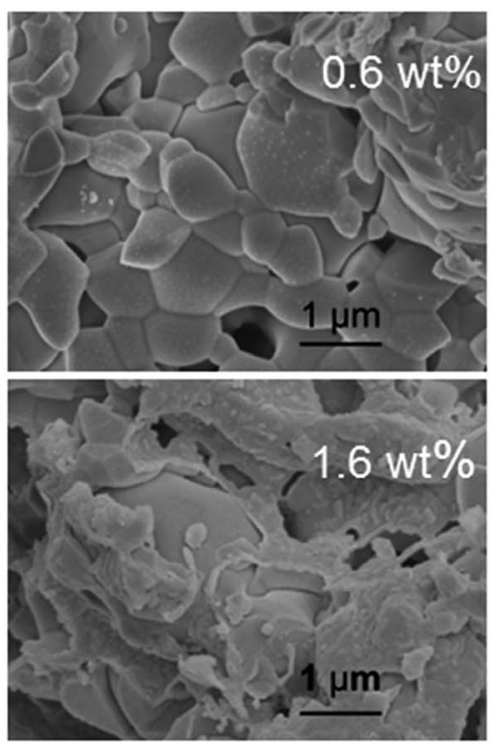

Fig. 2 Microstructure of the cells. (a) An example of cross-sectional SEM microstructure of a tested cell with a Ni-YSZ anode infiltrated with BCZYYb-0.6 wt\%, a YSZ electrolyte, a Gd $0.1 \mathrm{Ce}_{0.9} \mathrm{O}_{2}$ (GDC) layer and a $\mathrm{La}_{0.6} \mathrm{Sr}_{0.4} \mathrm{Co}_{0.2} \mathrm{Fe}_{0.8} \mathrm{O}_{3}$ (LSCF)-GDC cathode after being tested at $850{ }^{\circ} \mathrm{C}$, $800^{\circ} \mathrm{C}$ and $750^{\circ} \mathrm{C}$; this cell ran at $0.8 \mathrm{~V}\left(1.25 \mathrm{~A} \mathrm{~cm}^{-2}\right)$ at $750{ }^{\circ} \mathrm{C}$ for 50 hours; (b) anode microstructure of the Ni-YSZ cells infiltrated with BCZYYb after electrochemical tests.
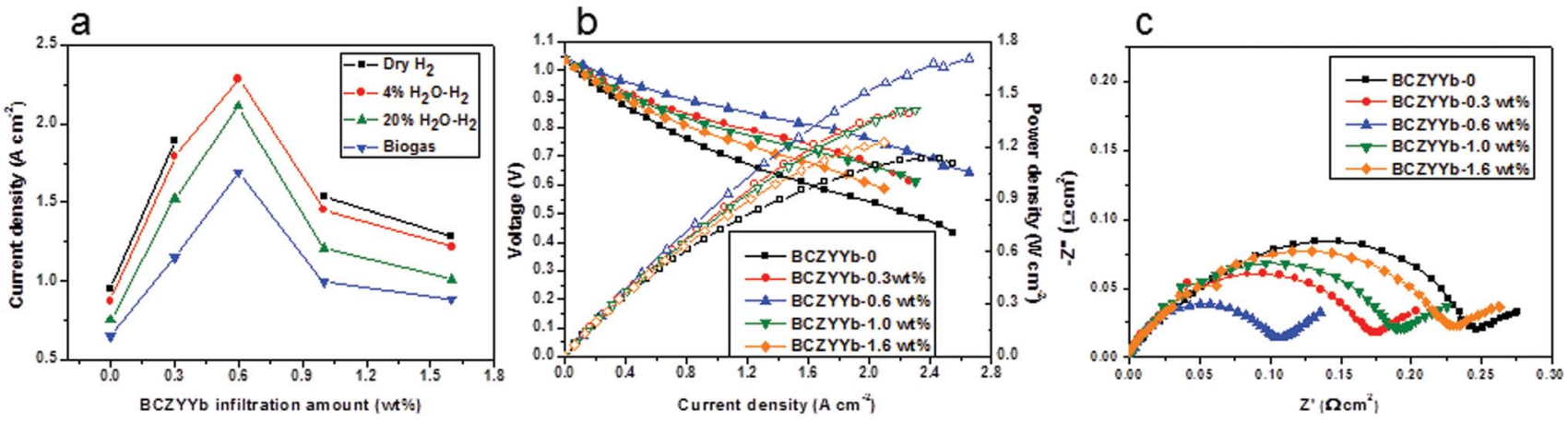

Fig. 3 Electrochemical performance of the cells. (a) Current densities of the cells infiltrated with different amounts of BCZYYb at a voltage of $0.8 \mathrm{~V}$ in dry $\mathrm{H}_{2}, 4 \% \mathrm{H}_{2} \mathrm{O}-\mathrm{H}_{2}, 20 \% \mathrm{H}_{2} \mathrm{O}-\mathrm{H}_{2}$ and biogas at $800{ }^{\circ} \mathrm{C}$, note: the current density of the cell Ni-YSZ/BCZYYb-0.6 wt\% in dry hydrogen is not shown in here as the current exceeded the current limitation of the Solartron 1280B; (b) current density-voltage and current density-power density curves of the cells, tested at $800^{\circ} \mathrm{C}$ in the recirculated biogas with a $20 \mathrm{ml} \mathrm{min}^{-1}$ flow rate at the anode and a $200 \mathrm{ml} \mathrm{min}{ }^{-1}$ airflow at the cathode; (c) comparative impedance spectra of the cells tested in open-circuit conditions at $800{ }^{\circ} \mathrm{C}$ after subtraction of the ohmic components.

transfer resistance) and low-frequency processes (assigned to diffusion resistance) were promoted. ${ }^{50}$ In the presence of an optimal amount of BCZYYb, the water-gas shift reaction and electrochemical reaction were enhanced. However, further increase in the infiltration will block the nickel active site for electrochemical reaction. The series resistance of the cells was very small in a range from 0.093 to $0.029 \Omega \mathrm{cm}^{2}$. The cells in this case were taken from the same batch of the experiments. The thickness of the YSZ thin film was around $7( \pm 1) \mu \mathrm{m}$. So the theoretical ohmic resistance from YSZ was $0.0179 \Omega \mathrm{cm}^{2}$. The difference between observed and theory was thought to be due to leads and especially contacts. The slightly smaller series resistance of the infiltrated cells might be due to the more conductive electrode, or better current collection.

\subsection{Fuel utilisation and durability}

We expected that the fuel utilisation of a single cell was $73.3 \%$ when the biogas was developed in the above context. Table 1 shows theoretical fuel utilisation calculated in terms of flow rate and current density. We had changed different biogas flow rates to see the possibility to get the target fuel utilisation. We can see that theoretically the fuel utilisation can reach $50.0 \%$ when the flow rate is $20 \mathrm{ml} \mathrm{min}{ }^{-1}$ it is supposed that a 2 A current can be obtained.

Following on from this, various flow rates, 10, 20, 30 and $40 \mathrm{ml} \mathrm{min}{ }^{-1}$, were used and the current density-voltage and current density-power density curves of the cell at $750{ }^{\circ} \mathrm{C}$ are shown in Fig. 4a. The cathode flow rate was $200 \mathrm{ml} \mathrm{min}^{-1}$ to ensure an adequate supply of gas for the cathode. With a 
Table 1 Theoretical fuel utilisation of the cell using the biogas as the fuel

\begin{tabular}{lllll}
\hline Current & $10 \mathrm{ml} \mathrm{min}^{-1}$ & $20 \mathrm{ml} \mathrm{min}$ & $30 \mathrm{ml} \mathrm{min}^{-1}$ & $40 \mathrm{ml} \mathrm{min}^{-1}$ \\
\hline 2A & 99.9 & 50.0 & 33.3 & 25.0 \\
1A & 50.0 & 25.0 & 16.7 & 12.5
\end{tabular}

$10 \mathrm{ml} \mathrm{min}{ }^{-1}$ biogas flow, good current density was obtained (up to $1 \mathrm{~A} \mathrm{~cm}^{-2}$ ). This was very impressive current density with this low flow rate. The cell suffered serious fuel starvation at a current density above $1 \mathrm{~A} \mathrm{~cm}^{-2}$. This result matched well with Table 1 . When the biogas flow rate increased to $20 \mathrm{ml} \mathrm{min}^{-1}$, the current density of the cell was above $2 \mathrm{~A} \mathrm{~cm}^{-2}$. Further improvement in the current density was observed with a $30 \mathrm{ml} \mathrm{min}{ }^{-1}$ biogas flow. The cell had enough fuel supply and no severe fuel starvation was recorded. However, further increasing the flow rate to $40 \mathrm{ml} \mathrm{min}{ }^{-1}$ was not found efficient in terms of performance improvement and fuel utilisation. We used a $20 \mathrm{ml} \mathrm{min}^{-1}$ flow rate in order to get reasonable fuel utilisation and good electrochemical power output.

We attributed the high power generation to a well-designed cell structure and selected components. In the presence of BCZYYb, apart from oxygen ions transportation, proton transportation played a role as well. The complex reactions of dry reforming, steam reforming and water-gas shift reactions at the anodes were promoted by the BCZYYb. The cathode response measured in a three-electrode mode of this cell, shown in Fig. $\mathrm{S} 3, \uparrow$ indicated the cell performance could be improved by using other cathode in the future work.

The influence of the cathode air flow rate on the cell performance was investigated and the results are shown in Fig. 4b. Different flow rates, 0, 50, 100, 150, $200 \mathrm{ml} \mathrm{min}^{-1}$ were applied. The air flow rate at the cathode had significant influence on the cell performance, in particular at a high current density. The cell displays oxygen starvation when there was no air flow at the cathode. In this study, a $200 \mathrm{ml} \mathrm{min}^{-1}$ air supply was used to ensure enough air supply at the cathode. At $750{ }^{\circ} \mathrm{C}$, the cell generated a current of $2.2 \mathrm{~A} \mathrm{~cm}^{-2}$ when the voltage was $0.65 \mathrm{~V}$. At a fuel cell's operational voltage (generally a hydrogen fuel cell operates $0.7 \mathrm{~V}$ ), a current of $1.67 \mathrm{~A} \mathrm{~cm}^{-2}$ was obtained. It showed better performance at $850{ }^{\circ} \mathrm{C}$ (Fig. S4 $\dagger$ ), a current of $2.2 \mathrm{~A} \mathrm{~cm}^{-2}$ was achieved at $0.8 \mathrm{~V}$. To our best knowledge, these high current densities with biogas fuel were not previously reported in the literature. The maximum power densities in biogas were comparable to those in pure hydrogen, wet hydrogen and steam hydrogen (Fig. S4 $\dagger$ ). The main difference was seen in the OCV values of each gas (Fig. S5, S6 and S7 $\dagger$ ). The OCV of the cells will be discussed in Section 3.4.1. The maximum power density of the cell with a $20 \mathrm{ml} \mathrm{min}^{-1}$ biogas at $750{ }^{\circ} \mathrm{C}$ was $1.43 \mathrm{~W} \mathrm{~cm}^{-2}$, as shown in Fig. 4 a. From Fig. $4 \mathrm{~b}$, in some cases we cannot identify the maximum power densities, because of the maximum current limitation of the current source $(2.5$ (A)). From a rough linear extrapolation, the maximum power density could be $\sim 1.9 \mathrm{~W} \mathrm{~cm}^{-2}$ at $750{ }^{\circ} \mathrm{C}$ supplied with $200 \mathrm{ml} \mathrm{min}{ }^{-1}$ air to the cathode.

It seemed that the cells were stable over a wide temperature range and at different current densities $\left(0.1 \mathrm{~A} \mathrm{~cm}^{-2}, 0.5 \mathrm{~A} \mathrm{~cm}^{-2}\right.$ and $1 \mathrm{~A} \mathrm{~cm}^{-2}$, Fig. S8 $\dagger$ ). The durability of the cell at $750{ }^{\circ} \mathrm{C}$ was examined as shown in Fig. $4 \mathrm{c}$. The current density was $1.25 \mathrm{~A} \mathrm{~cm}^{-2}$ at $0.8 \mathrm{~V}$. The cell was stable for 50 hours with slight fluctuation during the day being possibly due to changes in room temperature and hence actual furnace temperature. The current-voltage curves were collected at a flow rate of $20 \mathrm{ml} \mathrm{min}{ }^{-1}$ biogas. This appeared to be the optimal flow rate, since any further increase, produced no significant improvement in the cell performance (Fig. 4a), but wasted fuel. From Table 1, we can see that the fuel utilisation was $31.2 \%$ if the current was $1.25 \mathrm{~A}$ (the active area was $1 \mathrm{~cm}^{2}$ ). Of course, high fuel utilisation can be obtained if the cell is operating at higher current density. An image of this cell after this test inserted in Fig. 4c shows no any obvious carbon deposition was found after operation for 50 hours at $750{ }^{\circ} \mathrm{C}$.

\subsection{Reaction mechanism}

3.4.1. In open circuit conditions. The theoretical gas compositions at $850^{\circ} \mathrm{C}, 800{ }^{\circ} \mathrm{C}, 750{ }^{\circ} \mathrm{C}$ and the experimental results of gas compositions of the cell BCZYYb-Ni-YSZ/YSZ/ GDC/LSCF-GDC as recorded in a gas chromatograph at each temperature are shown in Fig. 5a. The main gases were $\mathrm{CO}$ and $\mathrm{H}_{2}$ in open-circuit conditions, which were the products of the
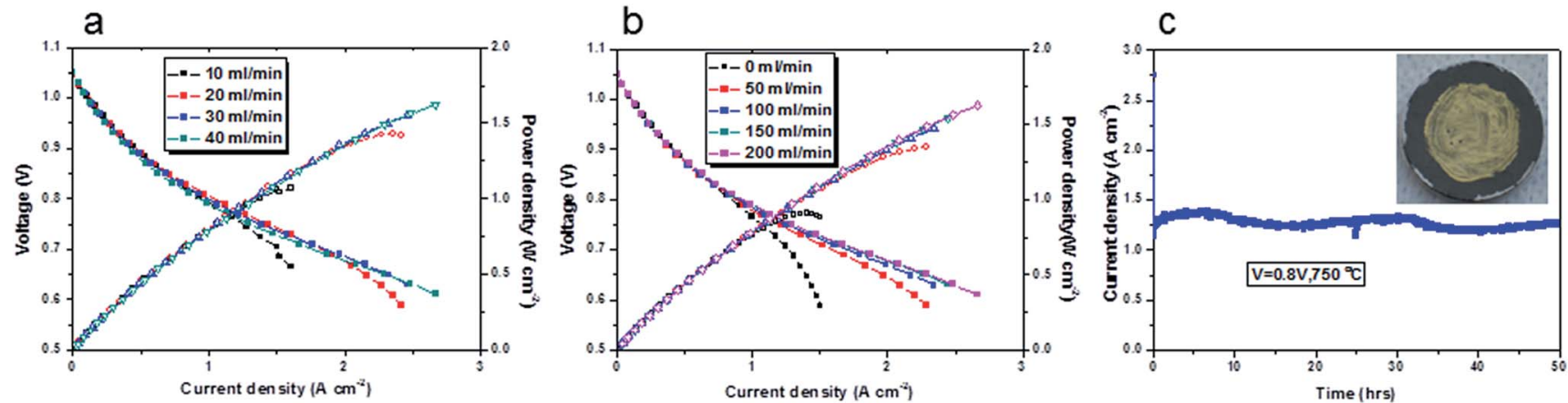

Fig. 4 Electrochemical performance of the cell with a structure of BCZYYb-0.6 wt\%-Ni-YSZ/YSZ/GDC/LSCF-GDC. (a) Influence of biogas flow rate on the cell performance at $750^{\circ} \mathrm{C}$, a $200 \mathrm{ml} \mathrm{min}{ }^{-1}$ air supplied at the cathode; (b) influence of cathode flow rate on the cell performance at $750{ }^{\circ} \mathrm{C}, 40 \mathrm{ml} \mathrm{min}-1$ biogas supplied at the anode; (c) durability of the cell tested at $750{ }^{\circ} \mathrm{C}$ with a $20 \mathrm{ml} \mathrm{min}^{-1}$ biogas flow at the anode and a $200 \mathrm{ml} \mathrm{min}-1$ air flow at the cathode, operational voltage was $0.8 \mathrm{~V}$, an image of the cell after test is inserted in the graph. 
reforming reactions. Take an example of the gases at $8500^{\circ} \mathrm{C}$, the theoretical values were $0.04 \mathrm{ml} \mathrm{min}^{-1} \mathrm{CH}_{4}, 2.35 \mathrm{ml} \mathrm{min}{ }^{-1} \mathrm{H}_{2} \mathrm{O}$, $1.69 \mathrm{ml} \mathrm{min}^{-1} \mathrm{CO}_{2}, 13.47 \mathrm{ml} \mathrm{min}^{-1} \mathrm{CO}$ and $16.77 \mathrm{ml} \mathrm{min}^{-1} \mathrm{H}_{2}$,

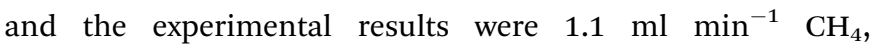
$2.8 \mathrm{ml} \mathrm{min}^{-1} \mathrm{H}_{2} \mathrm{O}, 3.7 \mathrm{ml} \mathrm{min}{ }^{-1} \mathrm{CO}_{2}, 18.8 \mathrm{ml} \mathrm{min}^{-1} \mathrm{CO}$ and $14.1 \mathrm{ml} \mathrm{min}^{-1} \mathrm{H}_{2}$. We found that the amounts of $\mathrm{CH}_{4}, \mathrm{H}_{2} \mathrm{O}$ and $\mathrm{CO}_{2}$ from the experimental results were slightly higher than the theoretical values, whereas the contents, $\mathrm{CO}$ and $\mathrm{H}_{2}$ were slightly lower. $\mathrm{CH}_{4}$ was thought to be mostly converted into $\mathrm{CO}$ and $\mathrm{H}_{2}$ by steam reforming (eqn (1)) and dry reforming (eqn (2)). The experimental results of conversion rate of methane were $83.9 \%, 79.2 \%$ and $71.7 \%$ of $\mathrm{CH}_{4}$ at $850{ }^{\circ} \mathrm{C}$, $800{ }^{\circ} \mathrm{C}$ and $750{ }^{\circ} \mathrm{C}$, which were slightly lower than theoretical values of $99.3 \%, 98.0 \%, 93.7 \%$ (Fig. $5 \mathrm{a}$ ). It has to be mentioned the above $\mathrm{CH}_{4}$ conversion rate was based the cell with BCZYYb. However there was not much difference on the $\mathrm{CH}_{4}$ conversion rate with or without $\mathrm{BCZYYb}$, only slighter higher $\mathrm{CH}_{4}$ conversion rate with infiltrated BCZYYb. The slightly lower methane conversion rate in comparison with theoretical one might be due to the less retention time of the gases in a small chamber in a button cell. This would be further improved in a large cell in industrial scale.

The open-circuit voltage of the cell operating in wet hydrogen at $850{ }^{\circ} \mathrm{C}$ was $1.13 \mathrm{~V}$ (Fig. S5 $\dagger$ ), which was close to theoretical value of $1.15 \mathrm{~V}$, showing that the YSZ membrane was gas tight. The OCV changed to $1.06 \mathrm{~V}$ when the pure hydrogen was humidified (Fig. S6 $\dagger$ ). When the gas was changed into $20 \%$ steam in hydrogen, the OCV decreased to $0.97 \mathrm{~V}$ (Fig. S7†), which was close to the theoretical value of $0.99 \mathrm{~V}$. The opencircuit voltages in the biogas at 850,800 and $750^{\circ} \mathrm{C}$ were $1.00 \mathrm{~V}$, $1.01 \mathrm{~V}$ and $1.03 \mathrm{~V}$, respectively (Fig. 5b, pink line), which matched well with the EMFs in theory in Fig. $5 \mathrm{~b}$ (blue line). Along with the theoretical OCV values in the biogas at different temperatures, the theoretical OCV values using $\mathrm{H}_{2}$ or $\mathrm{CH}_{4}$ as fuel were plotted against temperature. The calculation was done, assuming the $\mathrm{H}_{2}$ or $\mathrm{CH}_{4}$ to be directly oxidised. If the dominant reaction was the oxidation of $\mathrm{CH}_{4}$, there would be no significant change of OCV with temperature (Fig. 5b, red line). The experimental open-circuit voltage increased with the decrease in testing temperature, showing that hydrogen was the primary reactant, since the OCV of a hydrogen-fuelled cell increases with the decreasing temperature (Fig. 5b, black line).

3.4.2. Under load. Fig. 6a shows gas compositions of $\mathrm{CO}$, $\mathrm{CO}_{2}$, hydrogen and steam in open circuit condition and under current load. All the gas changed linearly with the current density. Water increased and hydrogen decreased with an increasing current. This suggested that hydrogen was oxidised into water electrochemically.

$$
\mathrm{H}_{2}+2 \mathrm{O}^{2-} \rightarrow \mathrm{H}_{2} \mathrm{O}+4 \mathrm{e}^{-}
$$

Similarly, carbon dioxide increased and carbon monoxide decreased with any increase in the current level. This indicated that carbon monoxide was being oxidised into carbon dioxide by a reaction with $\mathrm{H}_{2} \mathrm{O}$ producing $\mathrm{CO}_{2}$ and $\mathrm{H}_{2}$ (eqn (3)), with the hydrogen being further oxidised into $\mathrm{H}_{2} \mathrm{O}$. a
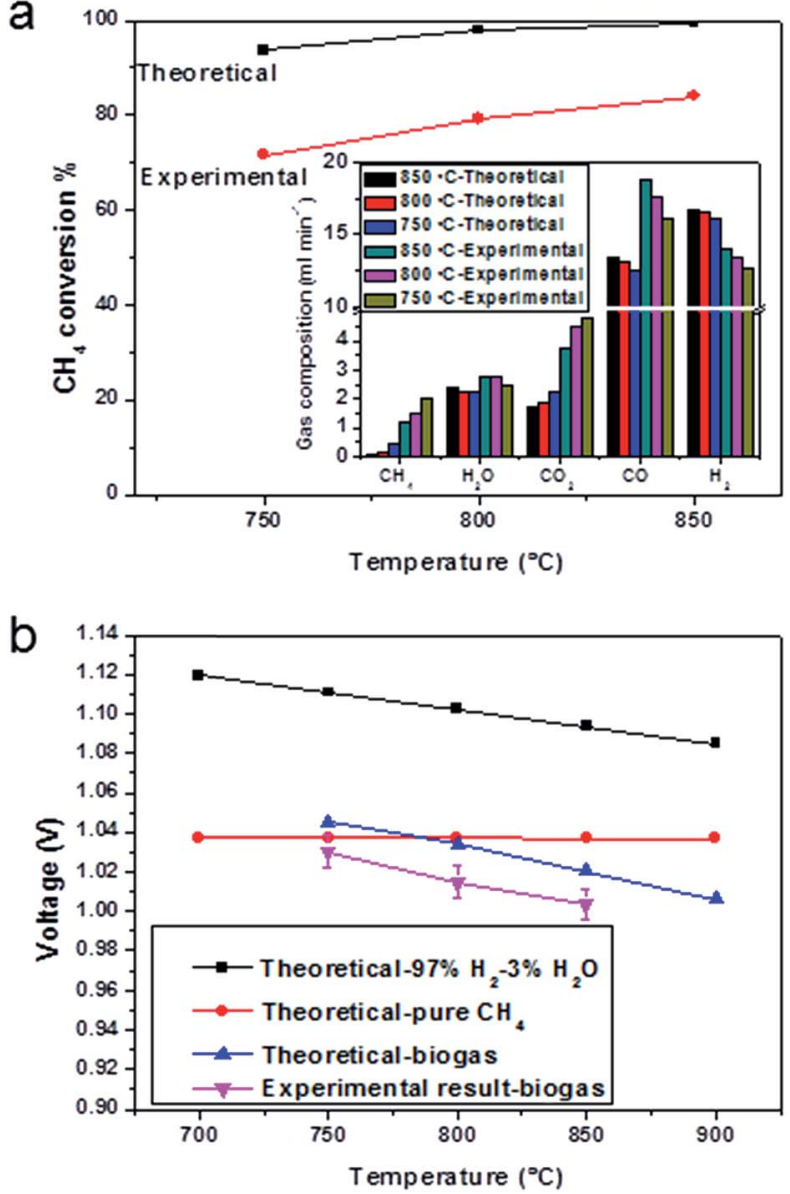

Fig. 5 Conversion rate of $\mathrm{CH}_{4}$ and open circuit voltages. (a) Experimental results and theoretical calculation of $\mathrm{CH}_{4}$ conversion rate, insert graph is the anode exhaust gas of the cell with a configuration of BCZYYb-0.6 wt\%/Ni-YSZ/YSZ/GDC/LSCF-GDC operating at various temperatures in open-circuit conditions supplied with a $20 \mathrm{ml} \mathrm{min}{ }^{-1}$ biogas. For comparison, theoretical gas compositions were also plotted; (b) experimental results of open circuit voltages with the recirculated biogas as the fuel and theoretical open-circuit voltages with $97 \% \mathrm{H}_{2}$, pure $\mathrm{CH}_{4}$ and theoretical equilibrium biogas, were used as the fuel (assuming hydrogen is only oxidised in biogas).

The anode exhaust gas composition also showed that gas almost reached equilibrium in most cases, which suggested excellent water-gas shift domination. The only deviation from equilibrium was observed at high current (i.e. $1 \mathrm{~A} \mathrm{~cm}^{-2}$ ). At $1 \mathrm{~A} \mathrm{~cm}^{-2}, 3.4 \mathrm{ml} \mathrm{min}{ }^{-1} \mathrm{CO}_{2}$ and $4.2 \mathrm{ml} \mathrm{min}^{-1} \mathrm{H}_{2} \mathrm{O}$ produced, which were the theoretical products for this current (the active cathode area is $1 \mathrm{~cm}^{2}$ ). With an increase in the current, there was more $\mathrm{H}_{2} \mathrm{O}$ produced than $\mathrm{CO}_{2}$. This indicated that as more oxygen was driven to oxidise hydrogen, the oxidation of hydrogen exceeded the rate of catalytic water-gas shift. Therefore the water-gas shift deviated from equilibrium. The gas utilisation obtained Fig. 6 a was $24.3 \%$, which was close to the theoretical value list in Table 1.

The $\mathrm{CH}_{4}$ content remained at the same level, during the test period, slightly changed with cell configurations and components and current load (Fig. 6b). This indicated that $\mathrm{CH}_{4}$ had mostly reformed in open-circuit conditions, and that direct 

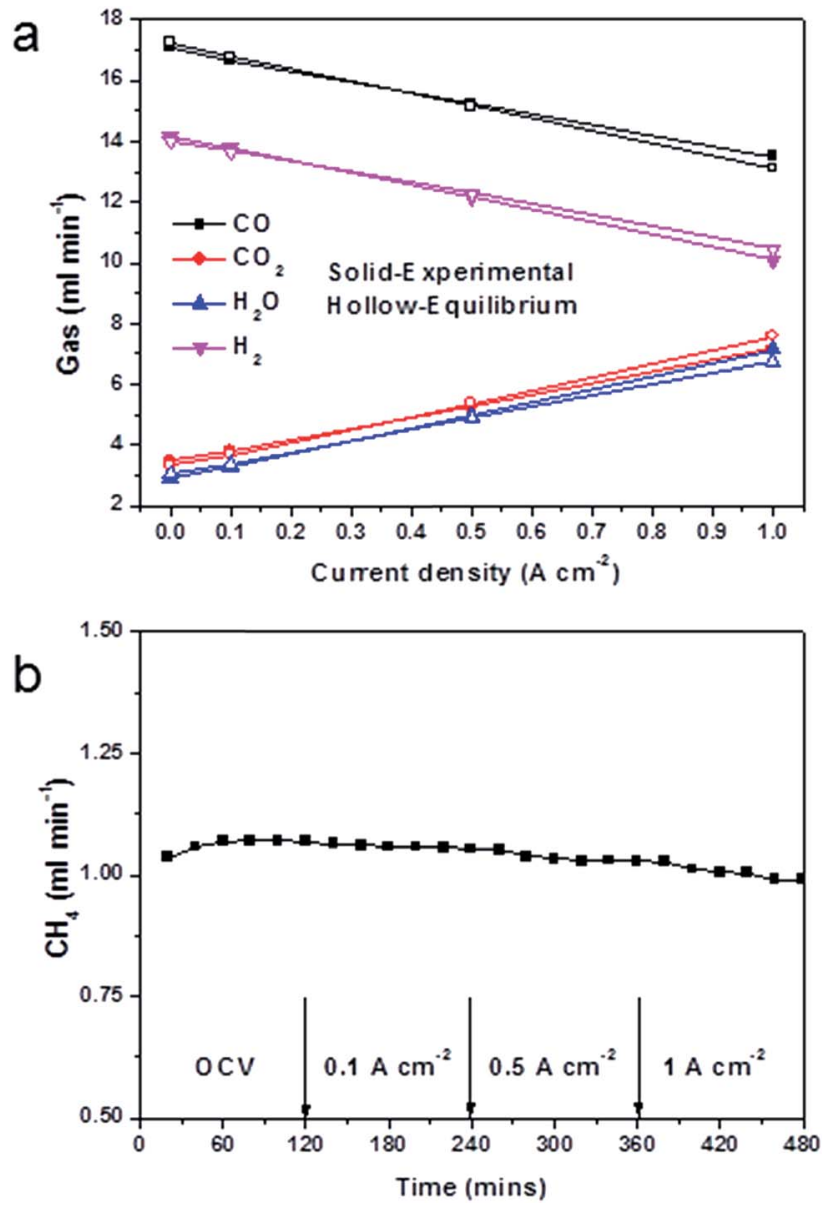

Fig. 6 Anode gas compositions and $\mathrm{CH}_{4}$ content of a cell at $850{ }^{\circ} \mathrm{C}$ under current load. (a) Experimental results of gas compositions at different current densities supplied with a $20 \mathrm{ml} \mathrm{min}^{-1}$ biogas, for comparison, theoretical equilibrium gas compositions were also included; (b) $\mathrm{CH}_{4}$ content in different conditions, test lasted for 2 hours for each condition.

oxidation of $\mathrm{CH}_{4}$ was not a prevalent reaction. This was in consistent with the OCV results in Fig. 5b. At current load, more products of $\mathrm{CO}_{2}$ and $\mathrm{H}_{2} \mathrm{O}$ promoted the dry reforming and steam reforming reactions, therefore less $\mathrm{CH}_{4}$ was found. It had been shown in the literature, that the conversion rate of methane increased with the $\mathrm{S} / \mathrm{C}$ ratio, and that with a $\mathrm{S} / \mathrm{C}$ ratio of 0.5 the methane conversion was $32 \% .^{51}$ The result in this research,

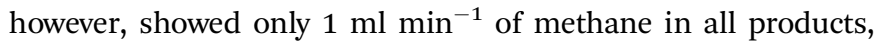
which would indicate that most of the methane had been reformed into hydrogen and carbon monoxide. It should, nevertheless, be noticed that the $\mathrm{S} / \mathrm{C}$ ratio was only 0.55 , and this value was much lower than the required steam amount in a single steam reforming system. This suggested that the participation of carbon dioxide in the reforming reaction was very effective.

\section{Conclusions}

In this study, an anode recirculation method was used to develop a biogas derived from an original composition of $63 \%$
$\mathrm{CH}_{4}$ and $37 \% \mathrm{CO}_{2}$, which was prone to carbon coking in the fuel cell operational temperatures. It was shown that anode recirculation was an effective route to use steam and $\mathrm{CO}_{2}$ to obtain a coking free biogas. The biogas used in this study was composed of $36 \% \mathrm{CH}_{4}, 36 \% \mathrm{CO}_{2}, 20 \% \mathrm{H}_{2} \mathrm{O}, 4 \% \mathrm{H}_{2}$ and $4 \%$ CO. Nickelbased solid oxide fuel cells was well-designed and the results showed that nickel anode was able to operate directly in this biogas directly at various temperatures and current densities without carbon deposition. We further developed a new anode structure of a $\mathrm{BaZr}_{0.1} \mathrm{Ce}_{0.7} \mathrm{Y}_{0.1} \mathrm{Yb}_{0.1} \mathrm{O}_{3-\delta}$ (BCZYYb)-Ni-YSZ and the cell with infiltrated anodes had a much better performance at $850{ }^{\circ} \mathrm{C}, 800{ }^{\circ} \mathrm{C}$ and $750{ }^{\circ} \mathrm{C}$. With a $20 \mathrm{ml} \mathrm{min}{ }^{-1}$ biogas supply at the anode and a $200 \mathrm{ml} \mathrm{min}{ }^{-1}$ air supply at the cathode, the highest power density of $1.43 \mathrm{~W} \mathrm{~cm}^{-2}$ at $750{ }^{\circ} \mathrm{C}$ was attained on a cell with a configuration of BCZYYB-Ni-YSZ/YSZ $(3 \mu \mathrm{m}) /$ $\mathrm{Gd}_{0.1} \mathrm{Ce}_{0.9} \mathrm{O}_{2} / \mathrm{La}_{0.6} \mathrm{Sr}_{0.4} \mathrm{Co}_{0.2} \mathrm{Fe}_{0.8} \mathrm{O}_{3}-\mathrm{Gd}_{0.1} \mathrm{Ce}_{0.9} \mathrm{O}_{2}$. This cell was able to operate in biogas for 50 hours without degradation. The utilisation of an anode exhaust gas (25\% in this study) to achieve the necessary internal reformation increased the system efficiency and fuel utilisation.

\section{Acknowledgements}

We would like to thank the EPSRC-DST India-UK Collaborative Research Initiative in Fuel Cells project EPI037016/1 "Advancing Biogas through Fuel Flexible SOFC" for funding this work. JI acknowledges the Royal Society for a Wolfson merit award.

\section{References}

1 C. C. Xu, J. W. Zondlo, M. Y. Gong, X. B. Liu and I. B. Celik, Proceedings of the Asme 8th International Conference on Fuel Cell Science, Engineering, and Technology 2010, 2010, vol. 1, pp. 233-241.

2 J. D. Huang and R. J. Crookes, Fuel, 1998, 77, 1793-1801.

3 S. Wongchanapai, H. Iwai, M. Saito and H. Yoshida, J. Power Sources, 2013, 223, 9-17.

4 S. T. Naumann and C. Myrén, J. Power Sources, 1995, 56, 4549.

5 J. Staniforth and K. Kendall, J. Power Sources, 1998, 71, 275277.

$6 \mathrm{~J}$. van herle, F. Marechal, S. Leuenberger, Y. Membrez, O. Bucheli and D. Favrat, J. Power Sources, 2004, 131, 127141.

7 R. Peters, R. Dahl, U. Kluttgen, C. Palm and D. Stolten, J. Power Sources, 2002, 106, 238-244.

8 K. Sasaki, K. Watanabe, K. Shiosaki, K. Susuki and Y. Teraoka, J. Electroceram., 2004, 13, 669-675.

9 A. Lanzini and P. Leone, Int. J. Hydrogen Energy, 2010, 35, 2463-2476.

10 C. Guerra, A. Lanzini, P. Leone, M. Santarelli and N. P. Brandon, J. Power Sources, 2014, 245, 154-163.

11 P. Aguiar, D. Chadwick and L. Kershenbaum, Chem. Eng. Sci., 2002, 57, 1665-1677.

12 S. H. Clarke, A. L. Dicks, K. Pointon, T. A. Smith and A. Swann, Catal. Today, 1997, 38, 411-423. 
13 R. J. Gorte, H. Kim and J. M. Vohs, J. Power Sources, 2002, 106, 10-15.

14 S. W. Tao and J. T. S. Irvine, Nat. Mater., 2003, 2, 320-323.

15 Y. H. Huang, R. I. Dass, Z. L. Xing and J. B. Goodenough, Science, 2006, 312, 254-257.

16 O. Costa-Nunes, J. M. Vohs and R. J. Gorte, J. Electrochem. Soc., 2003, 150, A858-A863.

17 M. A. Gerber, Review of Novel Catalysts for Biomass Tar Cracking and Methane Reforming, PNNL-16950, Pacific Northwest National Laboratory, Richland, WA, 2007.

18 D. Qin and J. Lapszewicz, Catal. Today, 1994, 21, 551-560.

19 A. Erdohelyi, J. Cserenyi and F. Solymosi, J. Catal., 1993, 141, 287-299.

20 M. F. Mark and W. F. Maier, J. Catal., 1996, 164, 122-130.

21 E. S. Putna, J. Stubenrauch, J. M. Vohs and R. J. Gorte, Langmuir, 1995, 11, 4832-4837.

22 T. Takeguchi, R. Kikuchi, T. Yano, K. Eguchi and K. Murata, Catal. Today, 2003, 84, 217-222.

23 C. M. Finnerty, N. J. Coe, R. H. Cunningham and R. M. Ormerod, Catal. Today, 1998, 46, 137-145.

24 Y. Kim, J. H. Kim, J. Bae, C. W. Yoon and S. W. Nam, J. Phys. Chem. C, 2012, 116, 13281-13288.

25 T. Papadam, G. Goula and I. V. Yentekakis, Int. J. Hydrogen Energy, 2012, 37, 16680-16685.

26 A. Hagen, J. F. B. Rasmussen and K. Thydén, J. Power Sources, 2011, 196, 7271-7276.

27 Y. Shiratori and K. Sasaki, J. Power Sources, 2008, 180, 738741.

28 D. Saebea, Y. Patcharavorachot and A. Arpornwichanop, J. Power Sources, 2012, 208, 120-130.

29 V. Liso, A. C. Olesen, M. P. Nielsen and S. K. Kaer, Energy, 2011, 36, 4216-4226.

30 G. Goula, V. Kiousis, L. Nalbandian and I. V. Yentekakis, Solid State Ionics, 2006, 177, 2119-2123.

31 H. D. A. L. Viana and J. T. S. Irvine, Solid State Ionics, 2007, 178, 717-722.
32 K. S. Blinn and M. L. Liu, J. Power Sources, 2013, 243, 24-28. 33 S. M. Fang, L. Bi, C. L. Yang, L. T. Yan, C. S. Chen and W. Liu, J. Alloys Compd., 2009, 475, 935-939.

34 L. Yang, S. Z. Wang, K. Blinn, M. F. Liu, Z. Liu, Z. Cheng and M. L. Liu, Science, 2009, 326, 126-129.

35 I. Luisetto, E. di Bartolomeo, A. D'Epifanio and S. Licoccia, J. Electrochem. Soc., 2011, 158, B1368-B1372.

36 F. Wang, W. Wang, R. Ran, M. O. Tade and Z. Shao, J. Power Sources, 2014, 268, 787-793.

37 C. Xia and M. Liu, Solid State Ionics, 2002, 152-153, 423-430. 38 T. Tsai and S. A. Barnett, Solid State Ionics, 1997, 98, 191-196.

39 C. Xia, F. Chen and M. Liu, Electrochem. Solid-State Lett., 2001, 4, A52-A54.

40 T. Tsai and S. A. Barnett, Solid State Ionics, 1997, 93, 207-217. 41 Y. J. Leng, S. H. Chan, K. A. Khor and S. P. Jiang, Int. J. Hydrogen Energy, 2004, 29, 1025-1033.

42 C. S. Ding and T. Hashida, Energy Environ. Sci., 2010, 3, 1729-1731.

43 K. Sasaki and Y. Teraoka, J. Electrochem. Soc., 2003, 150, A878-A884.

44 M. Powell, K. Meinhardt, V. Sprenkle, L. Chick and G. McVay, J. Power Sources, 2012, 205, 377-384.

45 S. R. Gamble, D. Neagu and J. T. S. Irvine, ECS Trans., 2013, 57, 1527-1532.

46 C. R. Jiang, J. J. Ma, A. D. Bonaccorso and J. T. S. Irvine, Energy Environ. Sci., 2012, 5, 6973-6980.

47 F. Han, R. Muecke, T. van Gestel, A. Leonide, N. H. Menzler, H. P. Buchkremer and D. Stover, J. Power Sources, 2012, 218, 157-162.

48 S. deSouza, S. J. Visco and L. C. de Jonghe, J. Electrochem. Soc., 1997, 144, L35-L37.

49 S. P. Jiang, Mater. Sci. Eng., A, 2006, 418, 199-210.

50 A. Hauch, M. Mogensen and A. Hagen, Solid State Ionics, 2011, 192, 547-551.

51 D. H. Prasad, H. I. Ji, H. R. Kim, J. W. Son, B. K. Kim, H. W. Lee and J. H. Lee, Appl. Catal., B, 2011, 101, 531-539. 